\title{
Traditional Nitrogen Removal Coupled with SND to Meet Advanced WWTP Standards at a Full Scale SBR Wastewater Treatment Facility
}

\author{
Charlie L. Martin Jr. ${ }^{1}$, Clayton J. Clark II ${ }^{*}$ \\ ${ }^{1}$ Water/Wastewater Department, Graceville, USA \\ ${ }^{2}$ Department of Civil and Environmental Engineering Florida A \& M University Tallahassee, Tallahassee, USA \\ Email: charmartin@msn.com, ${ }^{*}$ clark@eng.famu.fsu.edu, ${ }^{*}$ clayton.clarkii@famu.edu
}

How to cite this paper: Martin Jr., C.L. and Clark II, C.J. (2017) Traditional Nitrogen Removal Coupled with SND to Meet Advanced WWTP Standards at a Full Scale SBR Wastewater Treatment Facility. Journal of Water Resource and Protection, 9, 1169-1183.

https://doi.org/10.4236/jwarp.2017.910076

Received: August 16, 2017

Accepted: September 25, 2017

Published: September 27, 2017

Copyright $\odot 2017$ by authors and Scientific Research Publishing Inc. This work is licensed under the Creative Commons Attribution International License (CC BY 4.0).

http://creativecommons.org/licenses/by/4.0/

\begin{abstract}
A Florida wastewater treatment facility studied how Simultaneous Nitrification Denitrification (SND) coupled with traditional nitrogen removal would be used to meet the state's current advanced wastewater treatment nutrient criterion. This study examined the effect of these combined processes on the fate and transport of the nitrogen species during the treatment process. The effectiveness of nitrogen removal within the full scale sequential batch reactor system (SBR) and the extent of SND compared to nitrification and denitrification in the nitrogen removal process was also evaluated. Finally, the overall performance of the municipal wastewater treatment facility utilizing these combined processes was evaluated. Overall, this application reduced the total nitrogen to almost $6 \%$ of the permitted concentration of $3.0 \mathrm{mg} / \mathrm{L}$. The combination of both processes also resulted in an actual $\mathrm{NO}_{3}^{-} / \mathrm{NO}_{2}^{-}$concentration $93.7 \%$ lower than the acceptable theoretical $\mathrm{NO}_{3}^{-} / \mathrm{NO}_{2}^{-}$concentration, which also resulted in effluent Total Inorganic Nitrogen nearly $80 \%$ lower than the permitted $3.0 \mathrm{mg} / \mathrm{L}$ effluent concentration. Further, the process produced a composite Total Nitrogen concentration that was $74 \%$ lower than the permitted concentration. This coupling of SND with traditional nitrogen removal resulted in a highly effective process to reduce nitrogen in the municipal wastewater effluent which is also attractive for potential implementation due to the low cost expenditure incurred in its utilization.
\end{abstract}

\section{Keywords}

Nitrogen, Simultaneous Nitrification Denitrification (SND), Wastewater Treatment, Full Scale Facility 


\section{Introduction}

\subsection{Theoretical Background}

The removal of nitrogen within wastewater treatment plants utilize the microbial driven process better known as the Nitrogen Cycle, depicted in Figure 1 (You et al. 2009 [1]; Martin and Clark, 2016 [2]). The organic nitrogen within wastewater in engineered collections systems is converted into ammonia via the anaerobic microbial process termed as ammonification. In fact, this process results into $70 \%-90 \%$ of the nitrogen entering into water reclamation systems as ammonia-nitrogen (USEPA, 2010) [3]. Within such systems, the ammonia-nitrogen is converted to nitrate-nitrogen thru nitrification, which is the process by which autotrophic microorganisms convert ammonia-nitrogen to nitrate-nitrogen typically within an aerobic environment. This is followed by the process by which heterotrophic microorganisms within an anoxic environment convert the nitrate-nitrogen to nitrogen gas known as denitrification.

The current paradigm of most wastewater treatment plants, particularly those that are municipal in nature, is of a design that encourages nitrogen removal via promoting nitrification and carbonaceous biochemical oxygen demand (CBOD) removal simultaneously (Kumar and Lin, 2010) [4]. Such is counterintuitive to the denitrification process in that CBOD is utilized by the heterotrophic bacteria during respiration to convert nitrate-nitrogen to nitrogen gas. This may result in requirement of a carbon source addition to facilitate denitrification and/or the

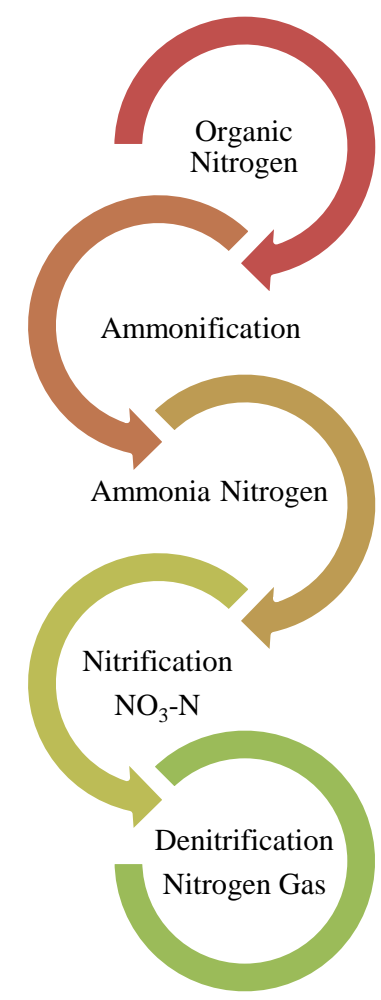

Figure 1. Fate of nitrogen within nitrogen removing wastewater engineered systems. 
incorporation of utilizing influent $\mathrm{CBOD}$ as the food source for the heterotrophic bacteria to convert nitrate-nitrogen to nitrogen gas. In contrast, nitrification and denitrification can occur simultaneously under low dissolved oxygen (DO) conditions such that the result is oxygen not penetrating the entire sludge floc. As a result, nitrification occurs across the exterior surface of the floc and denitrification occurs within the anoxic interior portions of the floc, hence the term simultaneous nitrification denitrification (SND) has been used to describe this phenomenon (USEPA, 2010) [3]. Simultaneous nitrification denitrification has been documented to be effective in full scale municipal aerated-anoxic orbal processes and oxidation ditches (Park et al. 2002) [5], as well as other varied wastewater treatment applications (Qi et al., 2007 [6]; Hwang and Weng, 2017 [7]; Ma et al., 2017) [8]. SND in specific relation to municipal wastewater treatment offers several advantages, including:

- it occurs without the requirement of separate aerobic and anoxic tanks;

- it occurs without the promotion of aerobic and anoxic conditions; thus, lacking cycling aeration on off periods;

- it eliminates the need for supplemental carbon addition to promote denitrification;

- and it occurs under low DO conditions, $0.5 \mathrm{mg} / \mathrm{L}$ or less (You et al., 2009) [1]. However, nitrification requires DO levels of $1.5 \mathrm{mg} / \mathrm{L}$ to be efficient (Wagner, 1997) [9]. The result is a reduction in energy usage when utilizing the SND process.

These beneficial characteristics were sought to be combined with established nitrogen removal techniques for application and evaluation at a full scale municipal wastewater treatment plant to meet state required effluent criterion.

\subsection{Site Background}

The City of Graceville Florida has a 4,164 m³/day Advanced Wastewater Treatment Plant (WWTP) which was placed into service January 1998. Based state requirements determined by the Florida Department of Protection (FDEP), the permitted treated wastewater effluent limits are as follows: total nitrogen (TN), consisting of organicnitrogen, ammonia-nitrogen, and nitrate/nitrite-nitrogen, at $3.0 \mathrm{mg} / \mathrm{L}$; total phosphorus at $1.0 \mathrm{mg} / \mathrm{L}$; CBOD of $5.0 \mathrm{mg} / \mathrm{L}$; and total suspended solids (TSS) at $3.0 \mathrm{mg} / \mathrm{L}$. The treatment plant process design included two sequential batch reactors (SBR) sharing positive displacement blower aeration. Coarse diffusion was utilized for aeration coupled with Aqua DDM mixing (Aqua-Aerobics Systems Inc. Patented Mixing; Rockford, IL). The design implemented primarily six phases of operation which were:

- Mix Fill: Default time of 60 minutes. Phase in which the influent is mixed with activated sludge; aeration was not provided in that air valve is closed. During this time period, anaerobic conditions were promoted to allow phosphate accumulating bacteria to release phosphorus.

- React Fill: Default time 120 minutes. Phase in which the influent was mixed 
with activated sludge to include on and off cycling of aeration in order to promote aerobic and anoxic conditions whereby nitrification and denitrification might take place. In addition, CBOD removal and phosphorus removal (luxury uptake) occurred. Influent valve and air valve to reactor was open.

- React: Default time 60 minutes. Considered to be polishing phase the remaining ammonia, CBOD, phosphorus, and nitrate not removed during the React Fill stage was reduced to permitted levels. Air valve was opened however, influent valve was closed.

- Settle: Default time 74 minutes. Mixing was halted and activated sludge was allowed to settle were upon suspended and settable solids are removed, known as clarification. Influent valve and air valve was closed.

- Decant: Default time 46 minutes. Supernatant was removed and the reactor decanted to predetermined low water level.

- Waste: Default time was 13 minutes. Activated sludge was removed to maintain steady Mean Cell Residence time (MCRT) or sludge age.

Default times of above indicated a total of 8 batches a day for this facility. The number of batches was increased or decreased based upon influent flow. Table 1 summarizes what the theoretical anticipated performance was as it related to influent concentrations and mass balance based on $4,164 \mathrm{~m}^{3} /$ day.

A plane view of the wastewater treatment facility in Graceville, Florida shows the location of the SBRs and blower room (see Figure 2). The view of the facility also shows that air lines used for aeration are buried. The airline used in the design consists of 10 ductile iron pipes, including a bell end with rubber gaskets. It was discovered in 2009 and 2014 that leaks resulted in a reduced amount of air flow into the reactors and low DO concentrations during aeration. Examination of the operational data of the results of these periods revealed that SND had occurred for nearly a month each time. The examination of the data also revealed that despite constant aeration accompanied with low DO concentrations, the permitted TN concentration limit of $3.0 \mathrm{mg} / \mathrm{L}$ was still met due to SND.

These results were interesting, yet, because of their unplanned nature, their effectiveness was not fully quantified. Therefore, the present study was initiated to provide validated results related to SND coupled with TN removal to meet advanced wastewater treatment criterion. The scope of this study sought to:

Table 1. Anticipated wastewater effluent prior to filtration at Graceville, Florida treatment facility.

\begin{tabular}{ccccc}
\hline & \multicolumn{2}{c}{ Influent (anticipated) } & \multicolumn{2}{c}{ Effluent (permitted) } \\
\hline & mg/L & mass kg/day & mg/L & mass kg/day \\
\hline Biochemical Oxygen Demand (5-day) & 119 & 496 & 5 & 21 \\
Total Suspended solids & 119 & 496 & 5 & 21 \\
Total Kjeldahl Nitrogen (TKN) & 30 & 125 & - & - \\
Total Phosphorus & 10 & 42 & 1 & 4 \\
Total Nitrogen & - & - & 3 & 12 \\
\hline
\end{tabular}




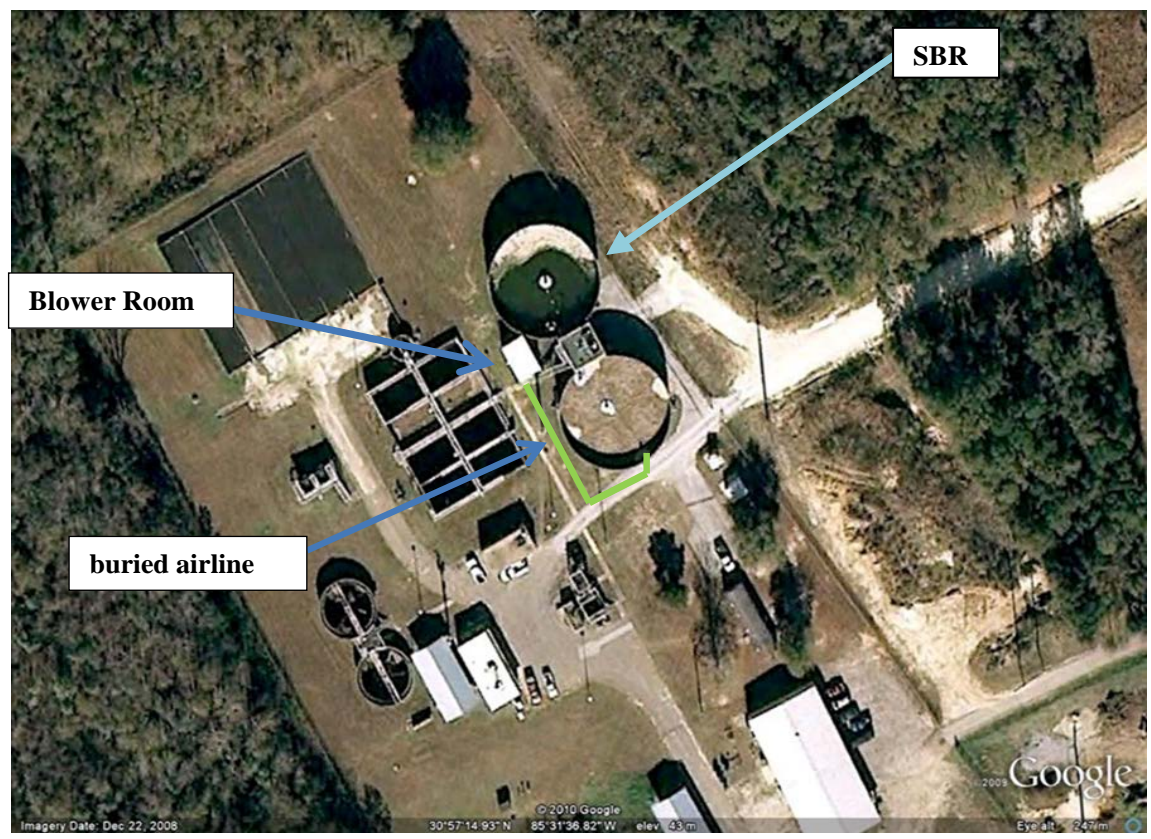

Figure 2. Plane view of city of Graceville advanced WWTP.

1) Examine the fate and transport of the nitrogen species during the treatment process within a fully functioning facility managing actual municipal wastewater flow;

2) Examine the effectiveness of nitrogen removal within the full scale SBR utilizing SND in conjunction with traditional nitrogen removal;

3) Characterize the extent of SND as compared to nitrification and denitrification in the nitrogen removal process; and

4) To provide further insight of the phenomenon of SND performance within municipal wastewater treatment facilities, especially when combined with traditional SBR nitrogen removal.

\section{Methods}

\subsection{Full Scale SBRs}

The City of Graceville Advanced WWTP utilizes two SBRs for treating domestic wastewater with a design flow of $4,164 \mathrm{~m}^{3} /$ day. The two reactors utilize eight batches per day with a batch volume consisting of $514 \mathrm{~m}^{3}$ at design flow. The SBRs share three positive displacement blowers. During the aeration period, only two blowers were placed into operation at one time. The discussion of the WWTP methodology and wastewater characteristics is important in differentiating the present full scale study from other experimental wastewater treatment tests. Two different Phase Times were utilized for optimum treatment efficiency during tests run during the two month period from July to August 2014. The two-month average daily flow was $1813 \mathrm{~m}^{3} /$ day with an average hydraulic retention time (HRT) of 41.1 hours which was similar to the Orbal processes described in (Park et al. 2002) [5]. The average mixed liquor suspended solids 
(MLSS) concentration was $4200 \mathrm{mg} / \mathrm{L}$ and the average mixed liquor volatile suspended solids (MLVSS) was $3288 \mathrm{mg} / \mathrm{L}$. The sludge retention time (SRT) was longer in that the two month average, 33 days, was similar to the Orbal processes described in (Park et al. 2002) [5]. Table 2 summarizes Phase Time 1.

The Phase Time 1 adjustments resulted in a batch fill time of 396 minutes with 3.63 batches/day or 1.82 batches/basin daily. Phase Time 1 consisted of an anaerobic period of 276 minutes (Mix Fill phase) followed by a 396-minute treatment time, which included a React Fill Phase of $120 \mathrm{~min}$ based influent coming into SBR and a React Phase of 276 min in which no more influent was entering the SBR. During this time the aeration structure consisted of the following: $1^{\text {st }}$ aeration period 180 minutes, aeration off 56 minutes, $2^{\text {nd }}$ aeration period 55 minutes, aeration off 65 minutes, $3^{\text {rd }}$ aeration period 35 minutes. Figure 3 summarizes the aeration structure as it relates to Phase Time 1.

Due to increased influent flows, Phase Time (s) 2 was utilized with its associated air structure. Table 3 summarizes the Phase Time 2.

This phase time adjustment resulted in a fill time of 180 minutes with 8 batches/day ( 4 batches/basin) and an anaerobic period of 60 minutes (Mix Fill phase) followed by a 180-minute treatment time (React Fill Phase 120 min. \& React Phase $60 \mathrm{~min}$.) with an aeration structure that consisted of the following:

The $1^{\text {st }}$ aeration period on for 120 minutes, aeration off 30 minutes, and a $2^{\text {nd }}$ aeration period 25 minutes. Figure 4 summarizes the aeration structure as it relates to Phase Time 2.

\subsection{Sampling \& Analysis}

Eight (one per week) 24-hour flow-proportioned influent and effluent composite samples were taken during the months of July - August. Influent and effluent composite samples were analyzed per Standard Methods [10] for the Examination of Water and Wastewater (SM), the Environmental Protection Agency

Table 2. Summary of phase time 1 for SBRs $1 \& 2$.

\begin{tabular}{ccccccc}
\hline Phase & Mix Fill & React Fill & React & Settle & Decant & Batches/day \\
\hline minutes & 276 & 120 & 276 & 74 & 46 & 3.63 \\
\hline
\end{tabular}

Table 3. Summary of phase time 2 for SBRs $1 \& 2$.

\begin{tabular}{lcccccc}
\hline Phase & Mix Fill & React Fill & React & Settle & Decant & Batches/day \\
\hline minutes & 60 & 120 & 60 & 74 & 46 & 8.00 \\
\hline Air on 180 min & Air off $\mathbf{5 6}$ min & Air on 55 min & Air off 65 min & Air on 35min \\
\hline
\end{tabular}

Figure 3. Aeration structure of phase 1. 


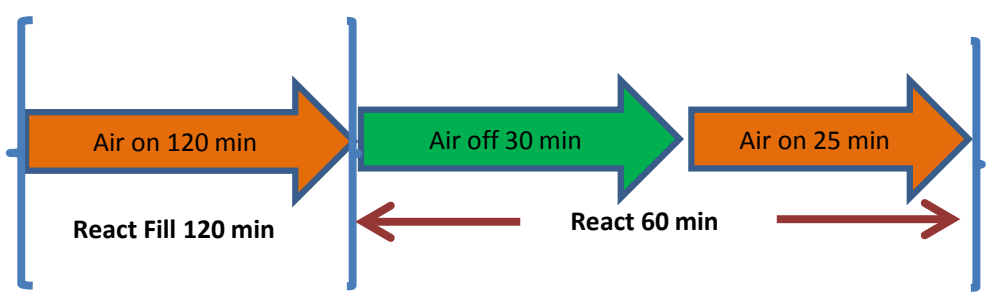

Figure 4. Aeration structure of phase 2.

(EPA) Methods for Chemical Analysis of Water and Wastes (USEPA, 1983) [11] and $\mathrm{HACH}^{\circledast}$ methods (https://www.hach.com/epa) [12]. Influent composite samples were analyzed for CBOD (Standard Method 5120B); total phosphorus as P (Standard Method 4500P E); ammonia as N Salicylate Acid method $\left(\mathrm{HACH}^{\circ}\right)$; cadmium reduction method ( $\left.\mathrm{HACH}^{\circ}\right)$; $\mathrm{pH}$; and TSS (Standard Method 2540D). Effluent composite samples were also analyzed for $\mathrm{NO}_{3} / \mathrm{NO}_{2}$ as $\mathrm{N}$ (Standard Method $4500 \mathrm{NO}_{3} \mathrm{E}$ ); total phosphorus as $\mathrm{P}$ (Standard Method 4500P E); ammonia as N Salicylate Acid method $\left(\mathrm{HACH}^{\circ}\right)$; $\mathrm{pH}$; and TKN (EPA 351.2). Influent grab samples were conducted once per shift (twice daily) and were analyzed for $\mathrm{pH}$ and temperature using a Fisher scientific model 15 Accumet $\mathrm{pH}$ meter; reactive phosphorus as $\mathrm{P}$ (Standard Method $4500 \mathrm{P}$ E); $\mathrm{NO}_{3} / \mathrm{NO}_{2}$ as $\mathrm{N}$ cadmium reduction method $\left(\mathrm{HACH}^{\circ}\right)$; ammonia as $\mathrm{N}$ Salicylate Acid method $\left(\mathrm{HACH}^{\circ}\right)$.

Seventeen batches were sampled (8 from SBR1 \& 9 from SBR2) during the months of July - August 2014. The Phase Time 1 and Phase Time 2 sampling of batches both had samples taken at the start and end of aeration throughout the batch. The samples were analyzed for ammonia-nitrogen; reactive phosphorus as $\mathrm{P} ; \mathrm{NO}_{3} / \mathrm{NO}_{2}$ as $\mathrm{N}$, as described for influent grab samples; and $\mathrm{NO}_{2}$ as $\mathrm{N}$ (Standard Method). Dissolved oxygen and oxidation reduction potential (orp) measurements were taken within the reactor in at the time of each sample using the $\mathrm{HACH}^{\circ}$ sc200 DO meter and the PinPoint orp meter manufactured by American Marine Inc. The sample taken at the end of the batch was also analyzed for temperature and $\mathrm{pH}$ using a Fisher scientific model 15 Accumet $\mathrm{pH}$ meter.

In addition to the above influent flow-proportion, composite sampling was conducted during the fill time for six of the batches and analyzed for reactive phosphorus as $\mathrm{P}$ (Standard Method $4500 \mathrm{P} \mathrm{E}$ ); $\mathrm{NO}_{3} / \mathrm{NO}_{2}$ as $\mathrm{N}$ cadmium reduction method $\left(\mathrm{HACH}^{\circ}\right)$; and ammonia as $\mathrm{N}$ Salicylate Acid method $\left(\mathrm{HACH}^{\circ}\right)$. MLSS samples were taken at the start of Mix Fill (low water level) an analyzed per Standard Methods (Method 2540D).

\subsection{Wastewater Characteristics}

The city of Graceville, Florida had a census reported population of 2000 residents in 2014; its service area also included a 1500 bed State correctional facility, and a 500-bed work camp. All wastewater received was municipal in nature. Table 4 summarizes the influent 24-hour composite monthly averages for, Carbonaceous Oxygen Demand (CBOD), Total Suspended Solids (TSS), Ammonia as $\mathrm{N}\left(\mathrm{NH}_{4}-\mathrm{N}\right), \mathrm{NO}_{3} / \mathrm{NO}_{2}$ as $\mathrm{N}$, Total Phosphorus as $\mathrm{P}$, and Flow for the months of 
June-August 2014.

As stated earlier, influent samples were taken twice per day once shift and analyzed for $\mathrm{NO}_{3} / \mathrm{NO}_{2}$ as $\mathrm{N}$, ammonia-nitrogen, reactive phosphorus as $\mathrm{P}$ (Orth-P); $\mathrm{pH}$, and temperature. Table 5 summarizes the average influent grab results for both time periods July 2014 and August 2014.

\subsection{Calculation of SND Efficiency}

The Simultaneous Nitrification Denitrification (SND) efficiency was calculated based on the following equation (Third et al. [13]).

$$
\text { SND Efficiency }=\frac{\Theta-\Omega}{\Theta} \times 100 \%
$$

where $\Theta$ represents $\mathrm{NH}_{4}^{+}-\mathrm{N}_{\text {(oxidized) }}$ which is the amount of ammonia-nitrogen oxidized after the nitrification process, $\Omega$ represents $\mathrm{NO}_{\mathrm{x}}-\mathrm{N}$ (produced) which is the concentration of $\mathrm{NO}_{2}^{-}-\mathrm{N}$ and $\mathrm{NO}_{3}^{-}-\mathrm{N}$.

\section{Results and Discussion}

\subsection{Simultaneous Nitrification Denitrification}

The data related to the $1^{\text {st }}$ aeration period of both Phase Times was examined for SND due to the fact that the aeration periods were either preceded and or followed by anoxic conditions in which there was a halt in aeration. The DO concentration at the end of the React Fill, the end of the $1^{\text {st }}$ aeration period for Phase Time 2 or two hours into the $1^{\text {st }}$ aeration period of Phase Time 1, within both SBR1 and SBR2 was below detectable levels $(0.0 \mathrm{mg} / \mathrm{L})$. The DO concentration after the $1^{\text {st }}$ aeration period for Phase Time 1 (180 minutes) was also $0.0 \mathrm{mg} / \mathrm{L}$. The Ammonia-Nitrogen $\left(\mathrm{NH}_{4}^{+}-\mathrm{N}\right)$ concentration at the end of the Mix Fill phase (end of the anaerobic period) and the $\mathrm{NO}_{3}-\mathrm{NO}_{2}$-Nitrogen concentration at the end of the 1st aeration period was used to calculate the SND efficiency. For 17 batches sampled during the months of July 2014 - August 2014 at the full

Table 4. Influent composite monthly averages for Graceville WWTP for July - August 2014.

\begin{tabular}{ccccccc}
\hline Month & $\begin{array}{c}\mathrm{CBOD} \\
\mathrm{mg} / \mathrm{L}\end{array}$ & $\begin{array}{c}\mathrm{TSS} \\
\mathrm{mg} / \mathrm{L}\end{array}$ & $\begin{array}{c}\mathrm{NH}_{4}-\mathrm{N} \\
\mathrm{mg} / \mathrm{L}\end{array}$ & $\begin{array}{c}\mathrm{NO}_{3} / \mathrm{NO}_{2}-\mathrm{N} \\
\mathrm{mg} / \mathrm{L}\end{array}$ & $\begin{array}{c}\text { Total P } \\
\mathrm{mg} / \mathrm{L}\end{array}$ & $\begin{array}{c}\text { Flow } \\
\mathrm{m}^{3} / \text { day }\end{array}$ \\
\hline Jul-2014 & 163.4 & 47.7 & 23 & 0.55 & 3 & 1870 \\
Aug-2014 & 132.2 & 56.4 & 28 & 0.89 & 2.9 & 1768 \\
\hline
\end{tabular}

Table 5. Average influent grabs results for Graceville WWTP for July 2014 and August 2014.

\begin{tabular}{cccccc}
\hline Month & $\mathrm{NO}_{3} / \mathrm{NO}_{2} \mathrm{mg} / \mathrm{l}$ & $\mathrm{NH}_{3} \mathrm{mg} / \mathrm{l}$ & Orth.-P mg/l & $\mathrm{pH}$ & Temp ${ }^{\circ} \mathrm{C}$ \\
\hline July 2014 & 0.80 & 27.7 & 3.13 & 7.23 & 26.7 \\
August 2014 & 0.80 & 27.4 & 2.84 & 7.04 & 27.1 \\
\hline
\end{tabular}


scale municipal wastewater facility, the average SND efficiency was $52.8 \%$, compared to the SND rates of $7.7 \%$ and $44.9 \%$ within the smaller lab-scale sequencing batch reactors described by Guo et al. (2008) [14]. The maximum SND efficiency was found to be $93.6 \%$ with a median percentage of $51.9 \%$.

The $\mathrm{NH}_{4}^{+}-\mathrm{N}$ percent removal was also calculated for each batch during the $1^{\text {st }}$ aeration period at the full scale WWTP facility. During this period, the $\mathrm{NH}_{4}^{+}-\mathrm{N}$ removal average was calculated to be $68.6 \%$, reaching a maximum removal of $94 \%$ and having a median value of $72.9 \%$. Each of these values exceeded the $30 \%$ - 50\% range reported by Park et al. (2002) [5] occurring within the anoxic zone of aerated-anoxic Orbal process. The average of the $\mathrm{NH}_{4}-\mathrm{N}$ removed by all the batches examined via SND was 36\%, which is $6 \%$ higher than that of the WWTP (Orbal reactor) discussed by Park et al. (2002) [5]. The overall average $\mathrm{NH}_{4}^{+}-\mathrm{N}$ concentration at start of the $1^{\text {st }}$ aeration for the 17 batches was $5.3 \mathrm{mg} / \mathrm{L}$. Influent-flow proportioned composite sampling was conducted during the Fill time to determine the overall $\mathrm{NH}_{4}^{+}-\mathrm{N}$ concentration in six batches.

As stated earlier, flow-proportioned influent composite sampling was conducted during the Fill time of six batches during the months of July 2014 - August 2014 and was analyzed for Reactive Phosphorus as P (Standard Method $4500 \mathrm{P} \mathrm{E}), \mathrm{NO}_{3} / \mathrm{NO}_{2}$ as $\mathrm{N}$ cadmium reduction method $\left(\mathrm{HACH}^{\circ}\right)$, Ammonia as $\mathrm{N}$ Salicylate Acid method $\left(\mathrm{HACH}^{\circ}\right)$. In addition, the batch volume was determined for its respective fill time and the batch concentration of Ammonia as $\mathrm{N}$, $\mathrm{NO}_{3} / \mathrm{NO}_{2}$ as $\mathrm{N}$, and Reactive Phosphorus as $\mathrm{P}$ calculated. The average SND efficiency for the six batches during the $1^{\text {st }}$ aeration period was $62.7 \%$, which was 9.6\% higher than the batches where flow proportional composite sampling during the fill time was not conducted. For these batches, maximum SND efficiency was $95.4 \%$ with a median of $56.3 \%$. The ammonia-nitrogen $\left(\mathrm{NH}_{4}-\mathrm{N}\right)$ removal of the six batches was $67.9 \%$. The average of the $\mathrm{NH}_{4}-\mathrm{N}$ removed by these six batches via SND was $42.5 \%$, which is $12.5 \%$ higher than that of the Marshall WWTP (Orbal reactor) discussed by Park et al. (2002) [5]. The average percent nitrogen removal during the $1^{\text {st }}$ aeration period was $67.9 \%$, including a maximum of $86.6 \%$ and a median of $71.1 \%$.

\subsection{Actual vs Theoretical $\mathrm{NO}_{3}^{-} / \mathrm{NO}_{2}^{-}-\mathrm{N}$}

The overall theoretical batch $\mathrm{NO}_{3}^{-} / \mathrm{NO}_{2}^{-}-\mathrm{N}$ concentration was calculated using the overall batch $\mathrm{NH}_{4}-\mathrm{N}$ concentration of the multiple sample batches, in which composite sampling was conducted and the $\mathrm{NH}_{4}-\mathrm{N}$ concentration at the start of the $1^{\text {st }}$ aeration period in which composite sampling was not conducted. Table 6(a) and Table 6(b) summarize the percent difference of the theoretical \& actual effluent $\mathrm{NO}_{3} / \mathrm{NO}_{2}-\mathrm{N}$ concentration. The theoretical effluent $\mathrm{NO}_{3}^{-} / \mathrm{NO}_{2}^{-}-\mathrm{N}$ concentration calculated was $2.72 \mathrm{mg} / \mathrm{L}$ which is still nearly $10 \%$ lower than the City of Graceville's permitted TN concentration of $3.00 \mathrm{mg} / \mathrm{L}$. However in SBR 1 of this study, the actual $\mathrm{NO}_{3}^{-} / \mathrm{NO}_{2}^{-}-\mathrm{N}$ concentration was $92.2 \%$ lower for Phase Time 1 and $98.7 \%$ for Phase Time 2, while for SBR 2 the percentage differences 
Table 6. (a) Difference of the theoretical \& actual effluent $\mathrm{NO}_{3}^{-} / \mathrm{NO}_{2}^{-}-\mathrm{N}$ concentration in SBR1; (b) Difference of the theoretical \& actual effluent $\mathrm{NO}_{3} / \mathrm{NO}_{2}-\mathrm{N}$ concentration in SBR2.

(a)

\begin{tabular}{|c|c|c|c|c|c|}
\hline & \multicolumn{5}{|c|}{ Effluent } \\
\hline & & $\begin{array}{c}\text { Actual } \\
\mathrm{NO}_{3}^{-} / \mathrm{NO}_{2}^{-}-\mathrm{N}\end{array}$ & $\begin{array}{c}\text { Theoretical } \\
\mathrm{NO}_{3}^{-} / \mathrm{NO}_{2}^{-}-\mathrm{N}\end{array}$ & $\%$ difference & \\
\hline Date & Reactor & $\mathrm{mg} / \mathrm{L}$ & $\mathrm{mg} / \mathrm{L}$ & & Phase Time \\
\hline $7 / 8 / 2014$ & SBR1 & 0.10 & 2.20 & 95.5 & 1 \\
\hline $7 / 11 / 2014$ & SBR1 & 0.40 & 2.10 & 81.0 & 1 \\
\hline \multirow[t]{3}{*}{$8 / 2 / 2014$} & SBR1 & 0.00 & 2.82 & 100 & 1 \\
\hline & AVG & 0.17 & 2.37 & 92.2 & \\
\hline & & & median & 95.5 & \\
\hline $7 / 24 / 2014$ & SBR1 & 0.00 & 0.56 & 100.0 & 2 \\
\hline \multirow[t]{3}{*}{$7 / 26 / 2014$} & SBR1 & 0.10 & 3.88 & 97.4 & 2 \\
\hline & AVG & 0.05 & 2.22 & 98.7 & \\
\hline & & & median & 98.7 & \\
\hline
\end{tabular}

(b)

\begin{tabular}{cccccc}
\hline \multicolumn{5}{c}{ Effluent } \\
\hline Date & Reactor & $\mathrm{mg} / \mathrm{L}$ & $\mathrm{mg} / \mathrm{L}$ & & \\
\hline $\mathrm{NO}_{3}^{-} / \mathrm{NO}_{2}^{-}-\mathrm{N}$ & $\begin{array}{c}\text { Theoretical } \\
\mathrm{NO}_{3}^{-} / \mathrm{NO}_{2}^{-}-\mathrm{N}\end{array}$ & \% difference & \\
\hline $7 / 12 / 2014$ & SBR2 & 0.3 & 2.99 & 90.0 & 1 \\
$7 / 17 / 2014$ & SBR2 & 0.3 & 2.96 & 89.9 & 1 \\
$8 / 9 / 2014$ & SBR2 & 0.2 & 0.9 & 77.8 & 1 \\
$8 / 16 / 2014$ & SBR2 & 0.3 & 2.62 & 88.5 & 1 \\
$8 / 30 / 2014$ & SBR2 & 0.07 & 3.48 & 98.0 & 1 \\
& AVG & $\mathbf{0 . 2 3}$ & 2.6 & $\mathbf{8 8 . 8}$ & \\
& & & median & $\mathbf{8 9 . 9}$ & \\
$7 / 18 / 2014$ & SBR2 & 0.3 & 2.59 & 88.4 & 2 \\
$7 / 25 / 2014$ & SBR2 & 0.2 & 1.2 & 83.3 & 2 \\
& AVG & $\mathbf{0 . 2 5}$ & $\mathbf{1 . 9}$ & $\mathbf{8 5 . 9}$ & \\
& & & median & $\mathbf{8 5 . 9}$ & \\
\hline
\end{tabular}

for Phase Times 1 and 2 were $88.8 \%$ and $85.9 \%$ lower, respectively, when compared to the acceptable theoretical values. Overall, the percent difference between the actual $\mathrm{NO}_{3}^{-} / \mathrm{NO}_{2}^{-}-\mathrm{N}$ concentration for all batches evaluated in the SBRs and all Phase Times examined was 93.7\% lower than the predicted acceptable theoretical effluent concentration. Consequently, the actual effluent $\mathrm{NO}_{3}^{-} / \mathrm{NO}_{2}^{-}-\mathrm{N}$ concentrations of the sample batches show that the SND process reduced the Total $\mathrm{N}$ to $6.31 \%$ of the permitted concentration. Therefore, the combined SND and traditional nitrogen removal would produce a much more 
efficient and effect process of nitrogen removal.

\subsection{Overall Ammonia-Nitrogen Removal}

The batch $\mathrm{NH}_{4}-\mathrm{N}$ percent removal for all batches examined was $97.5 \%$ and the median removal was $100 \%$. The average DO concentration at the end of the batches was $2.1 \mathrm{mg} / \mathrm{L}$; however, three of the batches had DO concentrations of $0.0 \mathrm{mg} / \mathrm{L}$ which is contrary to the accepted DO concentration of $1.5 \mathrm{mg} / \mathrm{L} \mathrm{re}$ quired for efficient Nitrification (Wagner, et al. 1997) [9].

\subsection{Total Inorganic Nitrogen Removal}

The average inorganic TN effluent concentration of the batches examined was $0.64 \mathrm{mg} / \mathrm{L}$ which is nearly $80 \%$ lower than the permitted $3.0 \mathrm{mg} / \mathrm{L}$ effluent TN concentration. The average inorganic effluent TN percent removal was $92.6 \%$. The maximum inorganic effluent TN percent removal was $100 \%$ and the median inorganic effluent TN percent removal was $\sim 95 \%$ percent. Table 7 (a). and Table 7(b). Summarize the inorganic effluent TN percent removal of the examined batches.

Table 7. (a) Summary of the inorganic effluent TN percent removal in SBR1; (b) Summary of the inorganic effluent TN percent removal in SBR2.

(a)

\begin{tabular}{|c|c|c|c|c|c|c|c|}
\hline & & Influent & Effluent & & & & \\
\hline & & $\mathrm{NH}_{4}-\mathrm{N}$ & $\mathrm{NH}_{4}-\mathrm{N}$ & $\Delta \mathrm{NH}_{4}-\mathrm{N}$ & $\mathrm{NO}_{3} / \mathrm{NO}_{2}-\mathrm{N}$ & $\begin{array}{c}\text { Inorganic } \\
\text { TN }\end{array}$ & $\begin{array}{l}\text { Inorganic } \\
\text { Nitrogen }\end{array}$ \\
\hline Date & Reactor & $\mathrm{mg} / \mathrm{L}$ & $\mathrm{mg} / \mathrm{L}$ & & $\mathrm{mg} / \mathrm{L}$ & $\mathrm{mg} / \mathrm{L}$ & $\%$ removal \\
\hline $7 / 8 / 2014$ & SBR1 & 5.80 & 0.00 & 100.0 & 1.1 & 1.1 & 81 \\
\hline $7 / 12 / 2014$ & SBR1 & 6.00 & 0.01 & 99.8 & 0.3 & 0.31 & 95 \\
\hline $8 / 2 / 2014$ & SBR1 & 4.90 & 0.01 & 99.8 & 0 & 0.01 & 100 \\
\hline \multirow[t]{3}{*}{$8 / 7 / 2014$} & SBR1 & 8.00 & 0.03 & 99.6 & 1.5 & 1.53 & 81 \\
\hline & AVG & 6.18 & 0.01 & 99.8 & 0.73 & 0.74 & 89.3 \\
\hline & & & & & & median & 89.3 \\
\hline
\end{tabular}

(b)

\begin{tabular}{|c|c|c|c|c|c|c|c|}
\hline & & Influent & Effluent & & & & \\
\hline & & $\mathrm{NH}_{4}-\mathrm{N}$ & $\mathrm{NH}_{4}-\mathrm{N}$ & $\Delta \mathrm{NH}_{4}-\mathrm{N}$ & $\mathrm{NO}_{3} / \mathrm{NO}_{2}-\mathrm{N}$ & $\begin{array}{c}\text { Inorganic } \\
\text { TN }\end{array}$ & $\begin{array}{c}\text { Inorganic } \\
\text { Nitrogen }\end{array}$ \\
\hline Date & Reactor & $\mathrm{mg} / \mathrm{L}$ & $\mathrm{mg} / \mathrm{L}$ & & $\mathrm{mg} / \mathrm{L}$ & $\mathrm{mg} / \mathrm{L}$ & $\%$ removal \\
\hline $7 / 12 / 2014$ & SBR2 & 6 & 0.01 & 99.83 & 0.3 & 0.31 & 95 \\
\hline $7 / 13 / 2014$ & SBR2 & 4.83 & 0 & 100.00 & 0.3 & 0.3 & 94 \\
\hline $7 / 17 / 2014$ & SBR2 & 5.2 & 0 & 100.00 & 0.3 & 0.3 & 94 \\
\hline $7 / 26 / 2014$ & SBR2 & 4.6 & 0.12 & 97.39 & 0.1 & 0.22 & 98 \\
\hline $8 / 9 / 2014$ & SBR2 & 6.25 & 1.66 & 73.44 & 0.2 & 1.86 & 97 \\
\hline $8 / 16 / 2014$ & SBR2 & 6.5 & 0.12 & 98.15 & 0.3 & 0.42 & 95 \\
\hline \multirow[t]{3}{*}{$8 / 30 / 2014$} & SBR2 & 6.4 & 0.02 & 99.69 & 0.7 & 0.72 & 89 \\
\hline & AVG & 5.68 & 0.28 & 95.5 & 0.31 & 0.59 & 94.6 \\
\hline & & & & & & median & 94.8 \\
\hline
\end{tabular}


The mass balance of $\mathrm{NH}_{4}-\mathrm{N}, \mathrm{NO}_{3} / \mathrm{NO}_{2}-\mathrm{N}$, and Total Inorganic Nitrogen was calculated for the six batches in which flow-proportioned composite sampling was conducted. The average influent $\mathrm{NH}_{4}-\mathrm{N}$ concentration was $21.2 \mathrm{mg} / \mathrm{L}$ and the average influent flow was $530 \mathrm{~m}^{3}$. The resulting average $\mathrm{NH}_{4}-\mathrm{N}$ mass for the six batches was $11.0 \mathrm{~kg} / \mathrm{batch}$. After treatment, the average effluent $\mathrm{NH}_{4}-\mathrm{N}$ mass was $0.04 \mathrm{~kg} / \mathrm{batch}$ and $\mathrm{NO}_{3} / \mathrm{NO}_{2}-\mathrm{N}$ mass was $0.01 \mathrm{~kg} / \mathrm{batch}$, which resulted in an inorganic TN mass percent removal of $99.6 \%$. The 24-hour flow-proportioned influent and effluent composite sampling was conducted weekly thru out the months of July 2014 and August 2014 as required by permit. The effluent samples were analyzed for TKN, $\mathrm{NO}_{3} / \mathrm{NO}_{2}-\mathrm{N}, \mathrm{TP}, \mathrm{CBOD}$, and TSS per Standard Methods. Table 8 summarizes the effluent composite results for the period.

The two-month average for the TKN, the sum of the organicnitrogen and the ammonia-nitrogen, was $0.51 \mathrm{mg} / \mathrm{L}$, with a maximum composite sample concentration was $0.96 \mathrm{mg} / \mathrm{L}$ while the minimum composite sample was below detectable levels, $<0.2 \mathrm{mg} / \mathrm{L}$. The effluent TN composite averages for both months during the sampling period were lower than the TKN effluent concentrations and the nitrate concentrations of the plants utilizing the Orbal process discussed in Daigger et al. (2000) [15] in which the minimum of which was $2.93 \mathrm{mg} / \mathrm{L}$ (Hammonton WWTP); furthermore, the monthly nitrate average was significantly lower than those of the municipal wastewater treatment plants in the same study (Daigger et al., 2000) [15] in which the minimum was $1.1 \mathrm{mg} / \mathrm{L}$ (Elmwood WWTP). The two month average for $\mathrm{NO}_{3} / \mathrm{NO}_{2}-\mathrm{N}$ was $0.28 \mathrm{mg} / \mathrm{L}$, including a maximum composite sample concentration of $0.52 \mathrm{mg} / \mathrm{L}$ and a minimum composite sample of $0.05 \mathrm{mg} / \mathrm{L}$. The TN composite of $0.79 \mathrm{mg} / \mathrm{L}$ is $74 \%$ lower than the permitted concentration of $3.0 \mathrm{mg} / \mathrm{L}$. Additionally, no adverse effects were observed in CBOD or TSS removal.

The data suggest that the City of Graceville Wastewater Treatment plant should be able to maintain monthly TN effluent concentration levels of 0.50 $\mathrm{mg} / \mathrm{l}$ or less, well within the Florida Department of Environmental Protection

Table 8. Effluent composite results for August - July 2014.

\begin{tabular}{ccccccc}
\hline Day & $\begin{array}{c}\mathrm{CBOD} \\
\mathrm{mg} / \mathrm{L}\end{array}$ & $\begin{array}{c}\mathrm{TSS} \\
\mathrm{mg} / \mathrm{L}\end{array}$ & $\begin{array}{c}\mathrm{TKN} \\
\mathrm{mg} / \mathrm{L}\end{array}$ & $\begin{array}{c}\mathrm{NO}_{3} / \mathrm{NO}_{2}-\mathrm{N} \\
\mathrm{mg} / \mathrm{L}\end{array}$ & $\begin{array}{c}\text { Total } \mathrm{N} \\
\mathrm{mg} / \mathrm{L}\end{array}$ & $\begin{array}{c}\mathrm{TP} \\
\mathrm{mg} / \mathrm{L}\end{array}$ \\
\hline $7 / 7 / 14$ & 7 & 1.50 & $<0.2$ & 0.33 & 0.43 & 0.54 \\
$7 / 14 / 14$ & 2.1 & 1.3 & 0.50 & 0.10 & 0.60 & 0.46 \\
$7 / 21 / 14$ & $<2$ & 1.75 & 0.50 & 0.05 & 0.55 & 0.74 \\
$7 / 28 / 14$ & 6.57 & 1.00 & 0.47 & 0.11 & 0.58 & 1.08 \\
$8 / 4 / 14$ & 2.74 & 1.00 & 0.66 & 0.44 & 1.10 & 0.99 \\
$8 / 11 / 14$ & 2.07 & 1.00 & 0.96 & 0.43 & 1.39 & 0.69 \\
$8 / 18 / 14$ & 2.46 & 1.00 & 0.69 & 0.24 & 0.93 & 1.05 \\
$8 / 25 / 14$ & 4.76 & 1.3 & 0.20 & 0.52 & 0.72 & 0.60 \\
AVG & $\sim 3.8$ & 1.2 & 0.51 & 0.28 & 0.79 & 0.77 \\
\hline
\end{tabular}


proposed Nutrient Criterion for TN. This highly effective process in reducing the nitrogen in the waste effluent is also attractive for potential implementation to other waste water treatment plants due to the lack of cost expenditure incurred in its utilization. As wastewater treatment needs grow in higher population areas and the need for greater cost efficiency is required, the optimization and implementation of SND may provide an avenue for cost effective municipal wastewater treatment. Furthermore, the current paradigm of nitrogen removal can be complex in nature and is often simplified using Supervisory Control And Data Acquisition (SCADA) and other instrumentation without which these systems are often subject to operator error. The use of SND could aid in elimination of such cost prohibitive process equipment, especially for small rural communities with limited tax revenue. Therefore, there is potential benefit in combining SND and traditional nitrogen removal of municipal wastewater treatment in both larger and smaller communities.

\section{Conclusion}

The present research evaluated the treatment of municipal wastewater with traditional nitrogen removal combined with simultaneous nitrification denitrification. This evaluation of water treatment is unique as it is conducted at municipal full scale advance wastewater treatment facility in the city of Graceville, Florida. The WWTP utilization of the SND process resulted in a relatively high field scale SND efficiency of $52.8 \%$, compared to the lower rate efficiencies with lab-scale sequencing batch reactors. During this SND process, the $\mathrm{NH}_{4}^{+}-\mathrm{N}$ removal average was calculated to be $68.6 \%$, also exceeding removal seen in previous treatment procedures. Overall, application of SND resulted in effluent $\mathrm{NO}_{3} / \mathrm{NO}_{2}-\mathrm{N}$ concentrations of $0.05 \mathrm{mg} / \mathrm{L}$ which reduced the $\mathrm{TN}$ to $6.31 \%$ of the permitted WWTP concentration of $3.0 \mathrm{mg} / \mathrm{L}$. A major impact of the combination of SND and traditional nitrogen removal in the batches indicated that the combination of both processes within the batches resulted in an actual $\mathrm{NO}_{3}^{-} / \mathrm{NO}_{2}^{-}$concentration that was $93.7 \%$ lower than the acceptable theoretical $\mathrm{NO}_{3}^{-} / \mathrm{NO}_{2}^{-}$concentration. Such a reduction in nitrate concentration resulted in effluent Total Inorganic Nitrogen average of $0.64 \mathrm{mg} / \mathrm{L}$ which was nearly $80 \%$ lower than the permitted $3.0 \mathrm{mg} / \mathrm{L}$ effluent TN concentration. In addition, an average TN composite sample of $0.79 \mathrm{mg} / \mathrm{L}$ was produced which was $74 \%$ lower than the permitted concentration. Additionally, no adverse effects were observed in CBOD or TSS removal. This highly effective process in reducing the nitrogen in the waste effluent is also attractive for potential implementation due to the lack of cost expenditure incurred in its utilization.

\section{Acknowledgements}

The authors wish thanks Florida A \& M University, including the Title III Program for funding of this research. In addition, appreciation is expressed to the City of Graceville and the Civil and Environmental Engineering Department of 
the FAMU/FSU College of Engineering for their support. The authors wish to thank, above all, their Lord and Savior Jesus the Christ for guidance during this endeavor.

\section{References}

[1] You, J., Das, A., Dolan, E. and Zhi, Q.H. (2009) Ammonia-Oxidizing Archaea Involved in Nitrogen Removal. Water Research, 43, 1801-1809. https://doi.org/10.1016/j.watres.2009.01.016

[2] Martin Jr, C.L. and Clark II, C.J. (2016) Evaluation of Simultaneous Nitrification Denitrification in Full Scale SBR Municipal Wastewater Treatment Facility. International Journal of Water and Wastewater Treatment, 2, No. 2.

[3] United States Environmental Protection Agency (2010) Nutrient Control Design Manual, Report EPA/600/R-10/100. Office of Research and Development/National Risk Management Research Laboratory, Cincinnati.

[4] Kumar, M. and Lin, J. (2010) Co-Existence of Anammox and Denitrification for Simultaneous Nitrogen and carbon Removal-Strategies and Issues. Journal of Hazardous Materials, 178, 1-9. https://doi.org/10.1016/j.jhazmat.2010.01.077

[5] Park, H.-D., Regan, J.M. and Noguera, D.R. (2002) Molecular Analysis of Ammonia-Oxidizing Bacterial Populations in Aerated-Anoxic Orbal Processes. Water Science Technology, 46, 273-280.

[6] Qi, R., Yang, K. and Yu, Z.-X. (2007) Treatment of Coke Plant Wastewater by SND Fixed Biofilm Hybrid System. Journal of Environmental Sciences, 19, 153-159. https://doi.org/10.1016/S1001-0742(07)60025-4

[7] Hwang, C.-C. and Weng C.-H. (2017) Key Factors Contributing to Simultaneous Nitrification-Denitrification in a Biological Aerated Filter System Using Oyster Shell Medium. Environmental Protection Engineering, 43, 76-86.

[8] Ma, W., Han, Y., Ma, W., Han, H., Zhu, H., Xu, C., Li, K. and Wang, D. (2017) Enhanced Nitrogen Removal from Coal Gasification Wastewater by Simultaneous Nitrification and Denitrification (SND) in an Oxygen-Limited Aeration Sequencing Batch Biofilm Reactor. Bioresource Technology, 244, 84-91. https://doi.org/10.1016/j.biortech.2017.07.083

[9] Wagner, M., Rath, G., Koops, H.P., Flood, J. and Amann, R. (1996) In situ Analysis of Nitrifying Bacteria in Sewage Treatment Plants. Water Science Technology, 34, 237-244.

[10] American Public Health Association/American Water Works Association/Water Environment Federation (1998) Standard Methods for the Examination of Wastewater. 18 Edition, American Public Health Association/American Water Works Association/Water Environment Federation, Washington DC.

[11] United States Environmental Protection Agency (1983) Methods for Chemical Analysis of Water and Wastes, Report EPA-600/4-79-020, Method 351.2. Office of Research and Development, Cincinnati.

[12] $\mathrm{HACH}^{\circ}$ (2017) EPA Compliant Methods. HACH Company Website. Loveland, CO. https://www.hach.com/epa

[13] Third, K.A., Burnett, N. and Cord-Ruwisch, R. (2003) Simultaneous Nitrification and Denitrification Using Stored Substrate (PHB) as the Electron Donor in an SBR. Biotechnology and Bioengineering, 83, 706-720. https://doi.org/10.1002/bit.10708

[14] Guo, J., Peng, Y., Wang, S., Zheng, Y., Huang, H. and Wang, Z. (2009) Long-Term 
Effect of Dissolved Oxygen on Partial Nitrification Performance and Microbial Community Structure. Bioresource Technology, 100, 2796-2802.

https://doi.org/10.1016/j.biortech.2008.12.036

[15] Daigger, G.T. and Littleton, H. (2000) Characterization of Simultaneous Nutrient Removal in Staged, Closed-Loop Bioreactors. Water Environment Federation, 72, 330-339. https://doi.org/10.2175/106143000X137554

Submit or recommend next manuscript to SCIRP and we will provide best service for you:

Accepting pre-submission inquiries through Email, Facebook, LinkedIn, Twitter, etc. A wide selection of journals (inclusive of 9 subjects, more than 200 journals) Providing 24-hour high-quality service

User-friendly online submission system Fair and swift peer-review system Efficient typesetting and proofreading procedure Display of the result of downloads and visits, as well as the number of cited articles Maximum dissemination of your research work

Submit your manuscript at: http://papersubmission.scirp.org/

Or contact jwarp@scirp.org 